$\begin{array}{llllllll}\text { Studia } & \text { z } & \text { Dziejów } & \text { Rosji } & \text { i Europy } & \text { Środkowo-Wschodniej } & \text { - LiI-SI(2) } \\ \text { A } & \text { R } & \text { T } & \text { I } & \text { C } & \text { L } & \text { E } & \text { S }\end{array}$

Stefan Dmitruk

Lublin

\title{
Chełm Orthodox Diocese as Mentioned in the Gazeta Ludowa. Tygodnik Ilustrowany Weekly from 1915 to 1918
}

Zarys treści: Przedmiotem badania są wątki związane z prawosławną diecezją chełmską na łamach "Gazety Ludowej. Tygodnika Ilustrowanego" w latach 1915-1918. Badanie to próba omówienia funkcjonowania eparchii chełmskiej w Królestwie Polskim w okresie I wojny światowej bez ewakuowanego duchowieństwa i znacznej części wiernych w głąb Rosji.

Outline of content: The object of the study involves themes related to the Orthodox Chelm diocese that appeared in the Gazeta Ludowa. Tygodnik Ilustrowany weekly from 1915 to 1918. The study attempts to discuss the life of the Chełm eparchy in the Kingdom of Poland during the First World War after the clergy and the majority of believers had been evacuated into the depths of Russia.

Słowa kluczowe: prawosławna diecezja chełmska, ewakuacja ludności cywilnej w Rosji podczas I wojny światowej, ludowe partie polityczne, rewindykacja cerkwi prawosławnych

Keywords: Chelm Orthodox diocese, evacuation of civilians to Russia during World War I, peasant political parties, repossessions of Orthodox Churches

The history of the Orthodox Chełm diocese during the First World War is an unexplored area in Polish historiography. Researching it is difficult because source materials are scattered among many archives and libraries in Poland, Russia, Belarus and Ukraine, some having been lost in the aftermath of post-1914 events. Polish historians have dealt with selected issues relating to individual events covered by this research topic. ${ }^{1}$

${ }^{1} \mathrm{~J}$. Cabaj, Społeczeństwo guberni chelmskiej pod okupacją niemiecka i austriacka w latach I wojny światowej, Siedlce, 2006; A. Wrzyszcz, Gubernia chełmska. Zarys ustrojowy, Lublin, 1997; K.P. Pękała, abstract of a doctoral thesis entitled "Migracje ludności guberni chełmskiej w pierwszych latach 
One of the sources that allow exploring the past of the Chełm diocese, from 1914 to 1918 subordinated to the Russian Orthodox Church, are local press titles published in Polish. Launched in October 1915, Gazeta Ludowa. Tygodnik Ilustrowany was published in Lublin and Warsaw. The 1915-1917 volumes of this publication can be found in the collections of Lublin libraries: the Maria Curie-Skłodowska University, the John Paul II Catholic University of Lublin and the Hieronim Łopaciński Regional Library. ${ }^{2}$ The entire 1918 volume is stored at the Warsaw University Library. ${ }^{3}$ Even though the publication's run is incomplete, ${ }^{4}$ an attempt has been made to study the Orthodox Chełm diocese during the First World War as it featured in the weekly. The limiting dates are 31 October 1915 on which the first Gazeta Ludowa issue appeared, and 24 November 1918 (issues 46-47 for 1918). The last Gazeta Ludowa issue follows the Polish Legions commander Józef Piłsudski's (1867-1935) return from the Magdeburg fortress to Warsaw where the Regency Council handed over civil authority to him.

The first issue of Gazeta Ludowa appeared on 31 October $1915 .{ }^{5}$ Initially, this political weekly was the press organ of the "Piast" Polish People's Party

wielkiej wojny (1914-1916)”, Lublin, 2012 (in the author's private collection); A. Głaz, "Ewakuacja ludności cywilnej z Lubelszczyzny latem 1915 r.”, Annales Universitatis Mariae Curie-Skłodowska, 56 (2001); K. Latawiec, "Ewakuacja cywilnej administracji ogólnej szczebla powiatowego z guberni lubelskiej latem 1915 r.", Wschodni Rocznik Humanistyczny, 1 (2004); id., "Ewakuacja organów władzy administracji ogólnej wyższego i niższego szczebla guberni lubelskiej w 1914 r.”, Radzyński Rocznik Humanistyczny, 2 (2002), pp. 43-55; G. Kuprianowicz, "Chełm jako ośrodek ukraińskiego ruchu narodowego w XIX i XX w. Zarys problematyki”, in: Na pograniczu kultur, ed. O. Popowicz, Przemyśl, 2000; J. Lewandowski, "Sprawa chełmska w czasie pierwszej wojny światowej”, in: Mychajło Hruszewski i jego Mała Ojczyzna - Chełmszczyzna w XIX-XX wieku, ed. G. Kuprianowicz, Chełm, 2011; K. Grzesiak, Diecezja lubelska wobec prawosławia w latach 1918-1939, Lublin, 2010.

${ }^{2}$ Katalog czasopism lubelskich, ed. H. Wolska, Lublin, 1974, p. 36; Katalog czasopism lubelskich. $G-M$, ed. I. Wójcik, Lublin, 2005, p. 14.

3 The author wishes to thank Dr. Grzegorz Figiel from the Hieronim Łopaciński Regional Public Library in Lublin for his help in obtaining a microfiched Gazeta Ludowa, volume for 1918.

4 Materials archived in these libraries include a very incomplete 1917 volume with just six issues preserved as well as the reasonably complete 1915 (without issue 1) and 1916 (without issue 25) volumes. Even though about $29 \%$ of issues are missing, it must be concluded that Gazeta Ludowa, is a relevant title for the study.

5 Analysis of the periodical's contents based on Gazeta Ludowa, issues published from 1915 to 1918. External description of the periodical based on: Bibliografia historii Polski XIX i XX wieku, vol. 3: 1864-1918, part 1, eds. S. Sokołowska, I. Ossowska, Warszawa, 2000, pp. 602-603; Katalog czasopism lubelskich, p. 36; Katalog czasopism lubelskich. G-M, p. 14; M. Willaume, "Działania zbrojne Rumunii podczas I wojny światowej w świetle doniesień lubelskiej Gazety Ludowej (1916-1917)", in: W stużbie Klio... Księga poświęcona pamięci Profesora Tadeusza Radzika, eds. J. Kłapeć, W. Kozyra, G. Kuprianowicz, R. Litwiński, M. Mazur, M. Sioma, R. Wysocki, Lublin, 2012, pp. 426-427. Daily dates are given according to the Gregorian calendar. It should be added that according to Bibliografia historii Polski (pp. 602-603) Gazeta Ludowa kept appearing until 1926. 
linked to Piłsudski's pro-independence faction. On 19 February 1917, Piast underwent a split which resulted in the emergence of the People's Union (hereinafter PU), ${ }^{6}$ with Gazeta Ludowa becoming a mouthpiece for the new body. The PU party united representatives of Kingdom of Poland peasant parties: the People's Party, Polish People's Association and National Peasant Association. As a new player on the political stage, it brandished right-wing and nationalist catchphrases targeted at peasants. The periodical printed Polish language texts containing right-wing, nationalist, pro-independence, anti-Russian, anti-Orthodox and pro-Catholic clerical slogans, giving wide support to the Polish Legions. In 1917, a large majority of Gazeta Ludowa articles was addressed to Polish peasants. It should be noted that in 1918 the periodical changed its profile from regional to nationwide and the editors stopped dealing with local issues. In September 1918, the Gazeta Ludowa editorial team avowed: "Gazeta Ludowa is the only newspaper that expresses the views of the People's Union, a newspaper owned by a company of farmers, a newspaper with a decidedly agrarian and independent character, a newspaper that defends the interests of peasants". ${ }^{7}$

Until the end of 1917, the weekly consisted of 16 pages, reduced to 12 in 1918. Each page measured 29 by $21 \mathrm{~cm}$. The paper's first publisher and editor was Władysław Korwin-Drożeński. ${ }^{8}$ Since issue 30 (1916), Gazeta Ludowa was published by the People's Publishing Company in Lublin, the responsible editor being Paweł Nikodem from Gazeta Ludowa 30 (1916) to at least Gazeta Ludowa 10 (1917) and Aleksander Olkiewicz from Gazeta Ludowa 13 (1917) onwards. In 1918, the publishing editor was Henryk Wyrzykowski (1884-1949) and the editorial team was expanded by literary editor Aleksander Olkiewicz (Gazeta Ludowa 30-45 [1918])..$^{9}$ From 1915 to 1917, the weekly was printed by the Lublin printing

${ }^{6}$ H. Cimek, "Ludowcy wobec idei parlamentu polskiego w latach 1918-1919", Polityka i społeczeństwo, 2 (2005), p. 29; id., "Tradycje dezintegracyjne i integracyjne w polskim ruchu ludowym w latach 1914-1918”, Res Historica, 20 (2005), p. 295; J. Mazurek, Kraj a emigracja. Ruch ludowy wobec wychodźstwa chłopskiego do krajów Ameryki Łacińskiej (do 1939 roku), Warszawa, 2006, p. 364.

7 Gazeta Ludowa, 38 (1918), p. 1. Quotations preserved the original Polish spelling.

${ }^{8}$ Gazeta Ludowa, 1 (1915), p. 15; ibid., 29 (1916), p. 15. An analysis of the periodical shows that M. Willaume (Działania zbrojne, p. 426), and Aleksandra Garlicka ("Prasa w Królestwie Polskim pod okupacją niemiecką i austriacką (1915-1918)", in: Prasa polska w latach 1864-1918, eds. Z. Kmiecik et al., Warszawa, 1976, p. 289) incorrectly identify the Gazeta Ludowa, editor. According to these researchers, the Lublin Gazeta Ludowa, was edited by Jan Dąbski (1880-1931), while authors of the Bibliografia historii Polski (pp. 602-603) state that from 1907 to 1914 Dąbski edited another title with the same name, first in Lwów and then in Cracow. Analysing the mastheads confirms the conclusions drawn by the latter.

9 Bibliografia historii Polski, pp. 602-603, contains incorrect information on Gazeta Ludowa. An analysis of the mastheads shows that dates on which editors and publishers took over their duties are different. A similar conclusion applies to dating the 1918 issues of the periodical (see footnote 13). 
presses of Jozafat Pietrzykowski ${ }^{10}$ and Andrzej Rozdoba, ${ }^{11}$ and in 1918, by the Warsaw printing press at 3 Świętokrzyska Street. In the final year of the Great War, the title was censored by the German Press Office. The Gazeta Ludowa editorial office was located at 17 Świętokrzyska Street in Warsaw in the German occupation zone and at 3 Kościuszki Street in Lublin in the Austrian occupation zone. The monthly circulation was $10,000 .{ }^{12}$ In 1918 , there were difficulties with printing and distributing the periodical as issues 1-29 appeared on 7, 14 and 21 July. ${ }^{13}$ From 28 July 1918 on (issue 30 ), the weekly again appeared at seven day intervals. ${ }^{14}$ In the already cited issue 30 (1918), the editors advised the readers that the title had not previously been distributed in areas occupied by the Germans. ${ }^{15}$

One of the topics discussed in Gazeta Ludowa are themes related to local Orthodox faith, and especially the Chełm diocese of the Russian Orthodox Church established in 1905 that covered the Lublin and Siedlce guberniyas and was extended to the Chełm guberniya since $1912 .{ }^{16}$ In pre-war days, the Chełm

10 The Pietrzykowski printing press, located at 4 Gubernatorska Street, printed Gazeta Ludowa, from the issue no. 3 (1915) to 3 (1917) as well as the issues 10, 13, 17, 18, 20 (1917). J. Pietrzykowski (1863-1932) was an owner of lithographic works located at 4 Gubernatorska Street in Lublin. The Pietrzykowski printing press played an important role on the Lublin publishing market. From 1914 to 1916, it printed such weeklies as Nowy Kurier Lubelski or Myśl Żydowska; see M. Trojnacka, "Pietrzykowski Jozafat (Józafat) (1863-1932)", in: Słownik biograficzny miasta Lublina, vol. 3, eds. T. Radzik, A.A. Wituski, J. Ziółek, Lublin, 2009, pp. 232-233; Willaume, Działania zbrojne, p. 426).

${ }^{11}$ From issue 31 (1916) to 4 (1917).

12 Gazeta Ludowa, 45, (1916), p. 3; Willaume, Działania zbrojne, s. 427.

13 Issue of 7 July 1918 numbered 1-15, issue of 14 July 1918 numbered 16-25 and issue of 21 July 1918 numbered 26-29. It should be noted that the editors wrongly marked these issues as belonging to volume 1 . From issue 30 (1918) the correct volume numbering was restored and issues were thenceforth marked as volume 4. Gazeta Ludowa, issues of 7, 14 and 21 July 1918 carried a subtitle "A weekly serving the fatherland, devoted to the cause of uniting the people" and a motto "The motto of Kosciuszko=GOD AND FATHERLAND=our motto". From issue 30 (1918) the issues carried a subtitle Świateczny Tygodnik Ilustrowany.

14 The issues of Gazeta Ludowa, distribution and printing require further research.

${ }^{15}$ Gazeta Ludowa, 30 (1918), p. 4.

16 On issues related to the Chełm diocese before 1914, see among others: L. Bieńkowski, "Chełmska diecezja prawosławna”, in: Encyklopedia katolicka, vol. 3, Lublin, 1979, p. 133; K. Latawiec, $W$ służbie imperium... Struktura społeczno-zawodowa ludności rosyjskiej na terenie guberni lubelskiej w latach 1864-1915, Lublin, 2007, pp. 214-251; Л. Третяк, Холмська духовна семінарія в 1875-1915 роках, in: Українці Холмщини і Підляшия: Історічна доля, духовна і матеріаьна култура впродовж віків. Збірник наукових праць, t. 2, Луцьк, 2010, pp. 279-287; J. Fedoryk, "Duchowieństwo prawosławne w Królestwie Polskim w latach 1875-1905", Lublin, 2010 (printout of a doctoral thesis stored in the Lublin Maria Curie-Skłodowska University Library), pp. 35, 224-225; id., Православне духовенство в Царстві Полському в 1875-1905 роках, Донецьк, 2013, p. 341; P. Sygowski, Stan ilościowy cerkwi na terenie Lubelszczyzny (prawosławna diecezja chetmska) w 1914 roku. Próba ustalenia stanu faktycznego, Wschodni Rocznik Humanistyczny 1 (2004), pp. 357-382; S. Dmitruk, "Prawosławne Bractwo Przenajświętszej Bogurodzicy w Chełmie (1879-1914)”, Lublin, 2012, a doctoral thesis, Maria Curie-Skłodowska 
eparchy struggled with a host of problems. The Orthodoxy to Roman Catholicism conversion process in the Lublin, Chełm and southern Podlachia regions that followed the 1905 toleration ukase caused long-term confessional, national, cultural and political repercussions. ${ }^{17}$ Confessional changes resumed, under wholly different conditions, during the First World War. The pre-1914 Orthodox press published in the Chełm diocese promoted Russian nationalist slogans and Slavophile ideas. ${ }^{18}$ These publications reflected the views of late nineteenth- and early twentieth-century Orthodox activists and contributed to the Polish perception of the Orthodox Church in the Chełm region and southern Podlachia as an instrument of Russification and an institution hostile to Polish nationalist slogans. On the other hand, Russian Orthodox intelligentsia in the Chełm diocese viewed the emerging Ukrainian nationalist movement as dangerous. ${ }^{19}$ The issues referred to above, unresolved until the war, escalated and transformed into confessional and national conflicts from 1915 to 1918.

After the Great War broke out, the Lublin region soon became a theatre of military operations. ${ }^{20}$ During the 1914 campaign in the Chelm and Lublin regions, both combatants destroyed numerous villages and farms. Over 700 people were deported to Austro-Hungary and a much higher number of Germans taken deep into Russia, the remaining civilians being subject to repressive measures. ${ }^{21}$ On 3 August 1914, the Lublin guberniya authorities announced that evacuation, a plan the Russians had worked on since 1909, had begun. ${ }^{22}$ The regional Russian administration

University Library in Lublin; id., "Życie monastyczne na terenie Królestwa Polskiego na przełomie XIX i XX w.”, Teka Komisji Historycznej. Oddział PAN w Lublinie, 6 (2009), pp. 73-83; С. Железнякович, История Яблочинского Свято-Онуфревского монастыря, vol. 2, Варшава, 2007; A. Szabaciuk, 'Rosyjski Ulster'. Kwestia chelmska w polityce imperialnej Rosji w latach 1863-1915, Lublin, 2013; Cabaj, Społeczeństwo guberni chetmskiej, p. 20. The necessity of conducting research devoted to the history of the Chełm Orthodox diocese from 1905 to 1914, and during the First World War must be noted.

17 Lewandowski, Sprawa chełmska, pp. 192, 204.

18 Dmitruk, Prawosławne Bractwo, pp. 319-326. These slogans were propagated, mostly in Russian, in periodicals linked to the Chełm Orthodox fraternity: Холмская Русь, Братская Беспда, and Холмскій Церковный Календарь.

19 Dmitruk, Prawosławne Bractwo, pp. 328-329.

${ }^{20}$ For the story of the 1914 military operations and their consequences, see among others: J. Pajewski, Pierwsza Wojna Światowa 1914-1918, Warszawa, 1991, pp. 233-237; K. Pękała, Tomaszów Lubelski w pierwszym roku "Wielkiej Wojny", in: Roztocze. Historia i kultura, vol. 1, Tomaszów Lubelski - Lubaczów, 2011, pp. 187-192; M. Zgórniak, 1914-1918. Studia i szkice z dziejów Wojny Światowej, Kraków, 1987, pp. 123-180; M. Hornyj, J. Makar, W. Makar, A. Saluk, Od deportacji do deportacji. Ukraińskie życie społeczno-polityczne na Chetmszczyźnie i Podlasiu (1915-1947). Badania. Wspomnienia. Dokumenty. W trzech tomach, vol. 1: Badania, Czerniowce, 2011, pp. 136-142.

${ }^{21}$ Hornyj, Makar, Makar, Saluk, Od deportacji do deportacji, pp. 140-141. In 1914 and 1915, the percentage of destroyed farms was $21.3 \%$ in the Biłgoraj county, $21.7 \%$ in the Zamość county, $31.7 \%$ in the Bialsk and Tomaszów county, $35.9 \%$ in the Hrubieszów county and $44.4 \%$ in the Chełm county.

22 More details in: Latawiec, Ewakuacja organów władzy, pp. 43-55. 
moved to Łuków between 26 August and 2 September 1914. Following the initial successes of Austro-Hungarian troops, the Russian army undertook an offensive in Galicia. The Habsburg forces withdrew from the Lublin and Chełm guberniyas and the evacuated Russian officials returned to their towns.

The most important event at the eastern front was the breakthrough at Gorlice that took place from 2 to 6 May $1915 .{ }^{23}$ In consequence, by the end of the summer of 1915, the Kingdom of Poland was wholly in German and Austrian hands. The Lublin and Chelm guberniyas, except for their northern slices where the headquarters of the German and Austrian armies in the eastern front were located, had been assigned to the Habsburg occupation zone whose capital was Lublin. ${ }^{24}$ As a result of these war events, the occupied territories included believers from the Chełm diocese.

As the Russian army retreated to the east, Russian administration was evacuated and civilians from Kingdom of Poland lands and western guberniyas of the Russian Empire displaced. ${ }^{25}$ The evacuation of administration conducted in June and July 1915 included officials of guberniya, county and some commune-level bodies. ${ }^{26}$ The evacuation of civilian $s^{27}$ was approved by the decision of General Nikolai Ivanov (1851-1919, commander-in-chief of the Southwestern Front) in early June $1915 .{ }^{28}$ In addition to displacing population from areas affected by military operations, Ivanov ordered that crops should be destroyed, food supplies removed and livestock seized. ${ }^{29}$ The consequences of this decision were slightly mitigated by an order issued by Grand Duke Nicolai Nikolaevich Romanov (1856-1929) of

23 More details in: M. Klimecki, Gorlice 1915, Warszawa, 1991.

${ }^{24}$ J. Lewandowski, Królestwo Polskie wobec Austro-Wegier. 1914-1918, Warszawa-Łódź, 1986, p. 66; J. Łojek, J. Myśliński, W. Władyka, Dzieje prasy polskiej, Warszawa, 1988, p. 78.

${ }^{25}$ On the issue of evacuation from the Lublin guberniya in 1915, see among others: Głaz, Ewakuacja ludności cywilnej; Latawiec, Ewakuacja cywilnej administracji. The latest study on this is the doctoral dissertation of Krzysztof Piotr Pękała entitled "Migracje ludności guberni". To understand the wider context, the following are worth reading: M. Korzeniowski, M. Mądzik, D. Tarasiuk, Tułaczy los. Uchodźcy polscy w imperium rosyjskim w latach pierwszej wojny światowej, Lublin, 2007; M. Korzeniowski, Na wygnańczym szlaku... Działalność Centralnego Komitetu Obywatelskiego Królestwa Polskiego na Białorusi w latach 1915-1918, Lublin, 2001; B. Demjaniuk, Bieżeńcy, Łomża, 2005; Бежанства 1915 года, еd. В. Луба, Беласток, 2000.

26 Wrzyszcz, Gubernia chetmska, p. 167.

${ }^{27}$ For more details on terminology-related controversies concerning the evacuation of civilians see S. Dmitruk, "Wspomnienia o powrocie z bieżeństwa w 1923 r. mieszkańca wsi Wilanowo", Białoruskie Zeszyty Historyczne, 43 (2015), fn. 3, pp. 215-216. In this article, the following terminology was adopted: evacuation means the general process, while bezhenstvo - the process involving Orthodox communities. The latter term is the result of the historical awareness of Polish Orthodox believers who systematically refer to that event as bezhenstvo. Thanks to them, this Russian word gained currency in academic discourse. On the other hand, I use the term "evacuation" to describe the planned departure of people and removal of state and Orthodox church property. For a full justification of these terms see the cited text.

${ }_{28}$ Głaz, Ewakuacja ludności cywilnej, p. 115.

29 Ibid. 
3 August $1915 .^{30}$ In promoting the displacement effort, the military and Chełm guberniya administration were joined by Orthodox clergy. ${ }^{31}$ According to the Ukrainian authors of a monograph From Deportation to Deportation (Od deportacji do deportacji), almost 185,000 Orthodox (about $47.9 \%$ of the entire population) had been evacuated from the Chełm guberniya, while the Grand Duchess Tatyana Committee, a Russian organisation aiding war victims, put the figure at 271,436 (about 55.2\% of the entire population), including 57,811 Poles. ${ }^{32}$ Following the 1915 evacuation, the number of Orthodox believers fell most drastically in the Biłgoraj (by 92.7\%), Hrubieszów (92.3\%) and Chełm (91.3\%) counties. ${ }^{33}$ As determined by Andrzej Wrzyszcz, $90 \%$ of the Orthodox and 20\% of Roman Catholics left the Chełm guberniya. ${ }^{34}$ Activists of the Russian Grand Duchess Tatyana Committee gave the number of people who left the Lublin guberniya as $51,070 .{ }^{35}$ Priests of the Roman Catholic diocese of Lublin determined that in 1915, the number of Orthodox in the diocese fell by 127,648 (about $88.1 \%$ ) and the number of Roman Catholics by 43,340 (about 5.4\%). ${ }^{36}$ Following the 1915 evacuation of civilians, the population of the Orthodox Chełm diocese decreased by about $90 \%$.

As noted above, one of the themes in Gazeta Ludowa journalism was the local Orthodox community during the Great War. The periodical's correspondents described the war-ravaged areas inhabited by the Orthodox in the Chelm region and southern Podlachia. According to an estimate made by Henryk Wierciński (1843-1923), in 1916 for the needs of the Lublin Civic Committee and published in the periodical, war losses in the Lublin guberniya (the Janów, Krasnystaw, Lublin and Puławy counties) amounted to $34,478,341$ roubles. ${ }^{37}$ An example was the village of Terebiń, burned down as the war front rolled through, although the Orthodox Church in the village remained intact. ${ }^{38}$ The damage was mostly caused by Russians during the evacuation. Accounts made by Gazeta Ludowa writers describe the consequences of population displacement carried out by the Russian troops in the summer of 1915. An unnamed farmer from Wólka Petrykowska near Sawin (Chełm county) stated that Russians burned the entire village. ${ }^{39}$ On the other hand "they [the Russians] burned the Dyle village down completely and almost all inhabitants departed with the troops. Most of them were Orthodox but a number of Poles went too". 40

\footnotetext{
${ }^{30}$ Ibid., p. 116.

31 Hornyj, Makar, Makar, Saluk, Od deportacji do deportacji, p. 144.

32 Ibid.; Korzeniowski, Mądzik, Tarasiuk, Tułaczy los, pp. 27-29.

33 Hornyj, Makar, Makar, Saluk, Od deportacji do deportacji, p. 145.

34 Wrzyszcz, Gubernia chełmska, p. 167.

35 Głaz, Ewakuacja ludności cywilnej, p. 124.

36 Ibid., p. 125.

37 Gazeta Ludowa, 19 (1916), p. 11.

38 Gazeta Ludowa, 3 (1915), p. 9

39 Gazeta Ludowa, 18 (1917), p. 10.

40 Gazeta Ludowa, 12 (1916), p. 10.
} 
A similar scene unfolded before soldiers of the 4th Infantry Regiment of the Polish Legions near Radzyń. Having entered an unnamed village, the legionnaires encountered a deserted Orthodox Church because the inhabitants together with the parish priest had been evacuated deep into Russia and "the parsonage [was] completely ransacked". ${ }^{41}$

In the village of Koniuchy in the Chełm county, Russian soldiers expelled the Ukrainians and a smaller number of Poles in the summer of $1915 .{ }^{42}$ As the buildings had not been put to fire, during harvest time of the year 1915 Roman Catholics moved in. This initiated the process of local Poles taking over abandoned farms. According to one of the correspondents, in early 1916 the situation at Hrubieszów and in its environs was dramatic. ${ }^{43}$ Six thousand inhabitants of the town, mostly Orthodox, had left, the neighbouring villages were ruined, while the crops rotted or remained standing in the fields. ${ }^{44}$ The account also stated that the Hrubieszów industry had been devastated by war, with four sugar plants, a distillery and numerous other facilities destroyed. The town was plagued by cholera and typhoid. In the Chełm region and southern Podlachia, epidemics wiped out about one thousand people by early 1916 . Their spread was facilitated by lack of medical care. In addition, the region was suffering from famine. ${ }^{45} \mathrm{~A}$ wider understanding of this topic is possible thanks to facts discovered by Father Krzysztof Grzesiak. According to the Lublin researcher, one of the consequences of bezhenstvo was the pauperisation of Chełm diocese believers resettled into other Russian guberniyas. ${ }^{46}$ The 1914-1915 campaigns led to the destruction of a large number of farms in the Lublin and Chełm guberniyas. Some of the abandoned buildings were appropriated by people from neighbouring villages, as well as a wave of Polish settlers from Galicia. ${ }^{47}$ In subsequent years, the occupying German and Austrian authorities intensively exploited the local peasant population. ${ }^{48}$ Following the 1915 evacuation, all Orthodox Churches had been closed and their documents, archives and church paraphernalia taken away. ${ }^{49}$ The parochial, demographic, economic and administrative network of the Chelm diocese was entirely obliterated during the war. The national and confessional structure of the Chełm region and southern Podlachia changed permanently and has never reverted to the pre-1915 condition.

${ }^{41}$ Gazeta Ludowa, 4 (1915), p. 10.

42 Gazeta Ludowa, 11 (1916), p. 10.

43 Gazeta Ludowa, 6 (1916), p. 8.

${ }^{44}$ Ibid., p. 8-10.

45 Ibid., p. 10.

${ }^{46}$ Grzesiak, Diecezja lubelska, p. 522.

47 Ibid.

${ }^{48}$ Lewandowski, Sprawa chełmska, s. 199; G. Kuprianowicz, "Ukraińskie życie kulturalno-oświatowe i ekonomiczne na Chełmszczyźnie i Południowym Podlasiu w latach 1918-1926", Rocznik Chetmski, 1 (1995), p. 173.

49 Grzesiak, Diecezja lubelska, p. 48. Research is being conducted to determine the route along which Church property, documents, believers and clergy had been transported. 
Between 1915 and 1918, religious life in the Chełm eparchy disappeared almost completely.

A relatively significant issue discussed on the pages of Gazeta Ludowa was the repossession and recovery of Orthodox Church buildings by the Roman Catholic Church during the Great War. The main reason for taking over Orthodox sanctuaries after 1915 was the evacuation of Russians and the bezhenstvo of the locals..$^{50}$ With the civilians departing deep into Russia, the Chełm eparchy was left with closed churches, the religious life of the Orthodox community practically vanished, and without the support of stable church structures social ties degenerated. From 1915 to 1919, in the Roman Catholic dioceses of Lublin and Podlachia a total of 160 Orthodox Church buildings had been taken over (70 in the Lublin diocese and 90 in the Podlachia diocese). The largest wave of recoveries took place after 11 November 1918, when the bishop of Podlachia Henryk Przeździecki (1873-1939) announced his decision on that matter. The process of reconsecrating Orthodox Churches was a result of a decree of the Chief of State of 16 December 1918. Father Grzesiak noted that from 1917 to 1919: "Over one hundred localities in the [Lublin] diocese filed petitions to take over Orthodox Churches. This initiative, almost always originating with the Catholic population, had a spontaneous and unprompted character" ${ }^{51}$ Decisions concerning recovery were made by the diocesan curia in Lublin with the consent of the Austrian occupation authorities and, after 11 November 1918, the Polish Ministry for Religious Confessions and Public Enlightenment. According to research made by Father Grzesiak, until the end of the First World War (11 November 1918), at least 15 Orthodox Churches had been consecrated in the Biłgoraj, Chełm, Zamość, Hrubieszów, Lublin, Tomaszów and Krasnystaw deaneries of the Orthodox Chełm diocese. ${ }^{52}$

The first sanctuary recovered for the needs of the Roman Catholic military ordinariate of the Austro-Hungarian army, was the church of the Exaltation of the Holy Cross in Lublin. The ceremony, which took place on 28 May 1916, was led by bishop Emeryk Bielik, vicar for the military ordinariate of the Austro-Hungarian Army in Vienna. ${ }^{53}$ As noted by Gazeta Ludowa: "With the efforts of the Austrian authorities, the Orthodox Church located in Lublin's Lithuanian Square was converted into a Catholic church to be used for the needs of the local Austrian garrison". ${ }^{54}$

On another occasion, Gazeta Ludowa printed detailed information, with some vitriolic commentary, on the recovery of the main church at the St. Anthony of

\footnotetext{
50 The issue of taking over Orthodox churches in the Chełm diocese based on: Grzesiak, Diecezja lubelska, pp. 122-125, 145.

51 Ibid., p. 124.

52 As determined by Grzesiak (ibid., pp. 126-144, 166), 15 churches had been recovered from 1916 to 1918 , of which 3 in 1916, 4 in 1917 and 8 until 11 November 1918.

53 Ibid., p. 125.

${ }^{54}$ Gazeta Ludowa, 23 (1916), p. 13.
} 
Kyiv (Pechersky) female convent in Radecznica near Szczebrzeszyn, which was planned to take place on 13 June $1916 .{ }^{55}$ The man behind the Radecznica sanctuary consecration was the then chaplain of the Command of the Polish Legions Group, Cyryl Strzemecki OFM (1870 - after 1938). ${ }^{56}$ The reconsecration of the former Russian Orthodox Church building in Radecznica was treated preferentially by Gazeta Ludowa's editors, as the periodical later printed an extensive, two-page account of the event. ${ }^{57}$

Brief notices about the recovery of the Zamość Orthodox Church appeared in the periodical in October $1916 .{ }^{58}$ In December 1916, the author of the article entitled Obrazek $z$ ziemi chetmskiej (A Scene from the Chelm Land) stated that Hrubieszów, a town with 15,000 inhabitants, had one Roman Catholic church and two Orthodox Churches. ${ }^{59}$ An interesting theme related to political postulates was the PU appeal printed in April 1917. The party proposed that the Chełm County Committee should hand over to the Roman Catholic Church three Orthodox Churches still functioning in the city and managed by the state administration. ${ }^{60}$ In support of their request, PU members argued that a single sanctuary was not enough for a parish of about 10,000 believers. According to the politicians, converting another building to a church would help remedy this situation. ${ }^{61}$ One of the Chełm sanctuaries was the centre of a military Greek Catholic parish, while in another Protestant services were held for the Austro-Hungarian garrison. ${ }^{62}$ For these reasons, the matter proved to be rather complex. The Gazeta Ludowa contents I have examined do not answer the question of whether the petition was received favourably by the civilian authorities. It should be reminded that Gazeta Ludowa was the mouthpiece of the PU, and therefore articles appearing in the periodical could be a form of exerting political and social pressure on decisions made by members of the Chełm County Committee. ${ }^{63}$

Another wave of recoveries took place in 1919. According to Father Grzesiak, in the Roman Catholic diocese of Lublin, 70 Orthodox Churches had been taken over and reconsecrated from 1917 to 1919 , with the majority in $1919 .{ }^{64}$ Such large numbers of occupied buildings and the accelerated pace of their consecration in

${ }^{55}$ Gazeta Ludowa, 24 (1916), p. 5.

56 Gazeta Ludowa, 24 (1916), p. 6. More details on Strzelecki's service can be found in: W.K. Cygan, W.J. Wysocki, W stużbie Bogu i Ojczyźnie. Stużba duszpasterska w polskich formacjach wojskowych 1914-1918, Mińsk Mazowiecki - Warszawa, 2012, p. 17 ff.

57 Gazeta Ludowa, 26 (1916), pp. 4-5.

58 Gazeta Ludowa, 39 (1916), p. 13.

59 Gazeta Ludowa, 50 (1916), p. 1.

60 Gazeta Ludowa, 17 (1917), p. 6.

${ }^{61}$ Ibid., pp. 6-7.

62 Ibid., p. 7.

63 This hypothesis needs to be analysed further.

${ }^{64}$ Grzesiak, Diecezja lubelska, pp. 123-145. 
1918 and 1919 was prompted by, among others, a concern that Orthodox believers from the Chełm diocese might bring back members of their clergy to reopen buildings which remained closed down at the time. ${ }^{65}$

The demographical structure of the Chełm diocese, broken down due to the 1915 bezhenstvo, and the consequent withering of parish life and a dearth of Orthodox clergy contributed to the proselytising efforts of Roman Catholic clergy. These efforts were led mostly by Jesuits from Galicia. ${ }^{66}$ According to Father Grzesiak, the most active among these missionaries were Father Marcin Dominik from Zakopane and Father Ignacy Mieloch.$^{67}$ In addition to their missionary work, the Jesuits promoted the ideas of union between Orthodoxy and Catholicism. ${ }^{68}$ The onset of this process was noted by Gazeta Ludowa in mid-March 1916. ${ }^{69}$ This should be supplemented by information on missions conducted by the Franciscans in the environs of Radecznica. Their five-day action in June 1916 culminated in the recovery of the town's church. ${ }^{70}$

On the other hand, missionary activities of the Greek Catholic Church in 1917-1918 focused on the person of Józef Bocian (1879-1926), the bishop of Łuck, and the efforts of Greek Catholic chaplains of the Austro-Hungarian army (such as Fathers Mateusz Chomań and Bazyli Kiryluk). ${ }^{71}$ The Greek Catholic Order of Saint Basil was active in the Chełm guberniya in early 1916. Gazeta Ludowa stressed that the monks petitioned the Holy See and Austrian authorities for mandatory reassignment to the Greek Catholic Church of former Uniates who converted to the Roman faith after the 1905 toleration decree. In addition, they proposed to classify the remaining Orthodox population in the Chełm region as Greek Catholic. ${ }^{72}$ In February 1916, the proposal was strongly criticised by the administrator of the Roman Catholic diocese of Lublin, Father Zenon Kwiek, who commented on the matter in the periodical.

As for some of the former Uniates now converted to the Latin rite, whose souls are in my care, I have no concern about the Ukrainian propaganda being in any wise successful. The deans of each of the deaneries declared that, following previous lamentable experiences, the people are absolutely opposed to any replacement of the Latin rite with another, being certain that only in the current rite they can be sure of their Catholic faith and firmly guarded against the designs of schismatic propaganda. ${ }^{73}$

${ }^{65}$ Ibid., p. 321.

${ }^{66}$ Ibid., s. 122, p. 463.

${ }^{67}$ Ibid., p. 123.

68 Ibid., p. 463.

${ }^{69}$ Gazeta Ludowa, 11 (1916), p. 13.

70 Gazeta Ludowa, 24 (1916), p. 5.

71 Grzesiak, Diecezja lubelska, s. 464, p. 468.

72 Gazeta Ludowa, 3 (1916), p. 3.

${ }^{73}$ Gazeta Ludowa, 8 (1916), p. 8. 
The confessional conflict between Roman Catholics and the Orthodox and nationality-based clashes among Poles, Ukrainians and Russians in the Chełm region and southern Podlachia escalated after 1864. Confessional antagonisms culminated after the Union of Brest was abolished in $1875^{74}$ and after the 1905 toleration ukase. It was then (from 1905 to 1909) that about 170,000 conversions took place. On the other hand, the nationalist conflicts between Poles and Russians were fanned by Russification efforts of the Tsarist administration that used the Russian Orthodox Church as its instrument. ${ }^{75}$ The climax of this conflict was reached in 1912 with the establishment of the Chełm guberniya. ${ }^{76}$ The long-term (1864-1914) policy pursued by Russian administrative authorities led to further escalation of the dispute during and after the First World War and cemented the "Catholic Pole" and "Orthodox Russian" (or "Orthodox Ruthenian") stereotypes. ${ }^{77}$ It was among the intricacies of the Polish-Russian conflict that the Ukrainian nationalist movement, opposed by both sides, emerged in the Chelm land and southern Podlachia. ${ }^{78}$ The Russian Orthodox press published in these areas at the turn of the twentieth century printed numerous anti-Polish and anti-Ukrainian articles. ${ }^{79}$

${ }^{74}$ For more details on the abolition of the Union of Brest in the Chełm diocese, see J. Lewandowski, Na pograniczu. Polityka władz państwowych wobec unitów Podlasia i Chełmszczyzny. 1772-1875, Lublin, 1996; H. Dylągowa, Dzieje Unii Brzeskiej (1596-1918), Warszawa-Olsztyn, 1996. For more details on disputes between Catholics and Orthodox in the late nineteenth and early twentieth century, see Fedoryk, "Duchowieństwo prawosławne", pp. 129-146; M. Roszczenko, "Kwestia tożsamości ruskiej (ukraińskiej) ludności Chełmszczyzny i Południowego Podlasia w XIX wieku", in: Mychajło Hruszewski i jego Mała Ojczyzna, pp. 143-150.

75 Roszczenko, Kwestia tożsamości ruskiej, pp. 143-150; Lewandowski, Sprawa chełmska, pp. 190-191; Fedoryk, Duchowieństwo prawosławne, pp. 73-79.

76 For more details on the reasons for separating the Chełm guberniya and its everyday life, cf. Wrzyszcz, Gubernia chetmska.

77 Szabaciuk, 'Rosyjski Ulster'. Kwestia chelmska, s. 271; Fedoryk, Duchowieństwo prawosławne, p. 73; Grzesiak, Diecezja lubelska, p. 502.

${ }^{78}$ For more details on the Ukrainian nationalist movement in the Chełm region and southern Podlachia from the 1870s to the outbreak of the First World War, the political stances of Galician Ukrainians and their impact on the Ukrainian population in the Siedlce and Lublin guberniyas, see Kuprianowicz, Chetm jako ośrodek ukraińskiego ruchu narodowego, p. 95 ff.; id., Холмське видання з Москви. "Холмський Украінський Календар на 1918 рік” як джерело для вивчення формування української нацйональної ідентичності холмщзаків, in: Mychajło Hruszewski i jego Mała Ojczyzna, pp. 206-207; J. Cabaj, "Postawy ludności Chełmszczyzny wobec kwestii przynależności państwowej swych ziem (1912, 1918-1919)”, Kwartalnik Historyczny, 99 (1992), p. 64 ff.; id., Społeczeństwo guberni chetmskiej, p. 160 ff.; L. Wasilewski, "Ukraińcy rosyjscy wobec Chełmszczyzny i Podlasia”, Kultura Polski, 8 (1918); J. Hrycak, Narodziny nowoczesnego narodu, Lublin 2000, pp. 92-105; W. Serczyk, Historia Ukrainy, Wrocław 2001, pp. 232-242, 251; Wrzyszcz, Gubernia chetmska, pp. 47-48; Szabaciuk, 'Rosyjski Ulster'. Kwestia chetmska, pp. 243-247; Fedoryk, Duchowieństwo prawosławne, pp. 23-24; Roszczenko, Kwestia tożsamości ruskiej, pp. 143-150. For a brief outline of the conflict between Russians and Ukrainians in the Chełm region and southern Podlachia see Dmitruk, Prawosławne Bractwo, pp. 326-329.

79 Dmitruk, Prawosławne Bractwo, pp. 319-333. 
On the other hand, pre-war Polish activists from the Lublin, Siedlce and Chełm guberniyas distributed and disseminated anti-Russian slogans. ${ }^{80}$

The continuation and aftermath of the late nineteenth- and early twentieth-century Polish-Russian struggle for the Chełm region and southern Podlachia that employed press articles and ephemera was found in Gazeta Ludowa publications from 1915 to 1917. A negative attitude versus Orthodoxy and Russianness was shown in November 1915 by an unidentified correspondent featuring in the "letters to the editor" column. He started his letter with the following statement: "Reymont, the famous writer, in his series of essays entitled $Z$ ziemi Chetmskiej mentioned that when entering Chelm he could not but feel an instinctive aversion for the city. He felt out of place in a town filled with dozens of gilded Orthodox Church domes, where Polishness was concealed, brought low and oppressed. The hillock with the archiepiscopal church appeared to him the lair of an unclean dragon spewing forth noxious fumes". ${ }^{81}$ Further on, he says that "the dragon is no more" because "gone are all those [...] who worked to ruin Polishness, proclaiming the Russian slogans of brotherhood of all Slavs with a view to making the Polish 'strain' repose on the breast of Great Russia too". ${ }^{82}$ The author pointed to archbishop Eulogi (Georgievski, 1868-1946) as the mastermind behind Russian propaganda. ${ }^{83}$ He proclaimed that Polish activists were about to restore national and religious unity, ${ }^{84}$ while regretting that Chełm was still not fully Polish, because "there is a large percentage of Jews whose worth remains to us an enigma". ${ }^{85}$ The writer affirmed that Polish schools and social organisations mushroomed in the city. Support for the Polish Legions idea grew and celebrations of the January Uprising anniversary were held. ${ }^{86}$ While military operations were ongoing east of Chełm in the autumn of 1915, the editors urged civilians not to give in to threats of Russian soldiers. The inhabitants of an unnamed village in southern Podlachia were offered as an example. ${ }^{87}$ According to one of Gazeta Ludowa journalists, the Polish population refused to be cowed by

80 Szabaciuk, 'Rosyjski Ulster'. Kwestia chetmska, pp. 189-197; D. Leśniewska, Problem unicki na łamach "Polaka", in: Martyrologia Unitów Podlaskich w świetle najnowszych badań naukowych. Unici Podlascy, vol. 1, red. J. Skowronek, U. Maksymiuk, Siedlce 1996, pp. 251-262.

81 Gazeta Ludowa, 3 (1915), p. 9. For the cited excerpt from the Władysław Reymont book (18671925), see W. Reymont, Z Ziemi Chetmskiej. Wrażenia i notatki, Warszawa, 1990, pp. 98-100.

82 Gazeta Ludowa, 3 (1915), p. 9.

${ }^{83}$ For the political role of archbishop Eulogi, see among others: Szabaciuk, 'Rosyjski Ulster'. Kwestia chetmska, pp. 189-197, 215-269; S. Dmitruk, "Obraz Dumy Państwowej w prasie prawosławnej diecezji chełmskiej”, in: $Z$ dziejów pewnego eksperymentu. Parlamentaryzm rosyjski na progu XX stulecia w kontekście kształtowania się świadomości politycznej narodów imperialnej Rosji, eds. A. Duszyk, K. Latawiec, M. Mądzik, Radom, 2008, pp. 197-209.

${ }^{84}$ Gazeta Ludowa, 3 (1915), p. 9.

85 Ibid., p. 10.

86 Ibid.

87 Gazeta Ludowa, 4 (1915), p. 10. 
Russian troops. ${ }^{88}$ Further accounts printed in Gazeta Ludowa in 1916 confirmed that the Russian army forced people to abandon their homes and depart deep into Russia's hinterland. ${ }^{89}$ The weekly summarised the evacuation effort by saying: "We are now free from the apostles of Orthodoxy and Russian culture". ${ }^{90}$

The editors promoted the Polish vision of the history of the Ukrainian population in the Chełm region and southern Podlachia, stressing the forced Russification of Ukrainians who were victims of Russian repressions in the late nineteenth and early twentieth centuries. Following the 1915 bezhenstvo, about one thousand Orthodox remained in the Biłgoraj region but they were not a threat to the local Polish population. ${ }^{91}$ The Gazeta Ludowa editors dubbed Orthodox activists a tool of the Russification process. ${ }^{92}$ In April 1917, Gazeta Ludowa writers stressed the need to undertake Polonisation efforts in the Chełm region and southern Podlachia. According to the journalists, educational work was conducive to Polonisation and helped spread literacy to wipe out the traces of Russification..$^{93}$ An analysis of those articles shows the increasingly radical nature of Polonisation slogans and the aggressive tone of Gazeta Ludowa's utterances that could well precipitate confrontation with the Ukrainian and Russian populations. The Catholic-Orthodox conflict ultimately escalated into, among others, the planned demolition of Orthodox Churches in the Chełm region and southern Podlachia in 1938. ${ }^{94}$

Gazeta Ludowa took notice of problems related to the return of Orthodox population to the former Chełm and Lublin guberniyas after the Treaty of BrestLitovsk had been signed between the Central Powers and Ukraine (9 February 1918) and Russia (3 March 1918). It did, however, refrain from commenting on these peace agreements and the controversial, given the Polish national interests, incorporation of the Chełm region and southern Podlachia into the Ukrainian People's Republic. ${ }^{95}$ By the end of 1918, thanks to the agreements, 250,000 refugees returned to the then Lublin general governorate occupied by Austro-Hungary. ${ }^{96}$

88 Ibid.

${ }^{89}$ Gazeta Ludowa, 7 (1916), p. 11; Gazeta Ludowa, 6 (1916), p. 8; Gazeta Ludowa, 11 (1916), p. 10.

90 Gazeta Ludowa, 6 (1916), p. 8.

91 Gazeta Ludowa, 9 (1916), p. 6.

92 Gazeta Ludowa, 11 (1916), p. 5.

93 Gazeta Ludowa, 17 (1917), p. 9.

94 See among others: Akcja burzenia cerkwi prawosławnych na Chełmszczyźnie i południowym Podlasiu w 1938 roku. Uwarunkowania, przebieg, konsekwencje, ed. G. Kuprianowicz, Chełm 2009; G. Kuprianowicz, 1938. Akcja burzenia cerkwi prawosławnych na Chełmszczyźnie i Południowym Podlasiu, Chełm,2008.

95 See among others: Lewandowski, Królestwo Polskie wobec Austro-Wegier, pp. 144-147; id., Sprawa chełmska, pp. 199-202; L. Grosfeld, "Sprawa Chełmszczyzny w 1918 r.", Kwartalnik Historyczny, 1 (1974), pp. 33-42; W.Z. Sulimierski, Oświata i życie kulturalno-społeczne Chetma w latach 1864-1939, Chełm, 2008, pp. 39-40.

96 See D. Sula, Powrót ludności polskiej z byłego Imperium Rosyjskiego w latach 1918-1937, Warszawa, 2013, pp. 93-107; Kuprianowicz, Ukraińskie życie kulturalno-oświatowe, pp. 172-173; Lewandowski, Sprawa chełmska, pp. 202-203. 
The issue of Orthodox inhabitants returning to their farms located in the Chełm guberniya which had been taken over by Poles must have been important. This theme was indeed discussed in an article in the weekly. In early August 1918, the periodical reported on a meeting of the Council of State of the Kingdom of Poland.${ }^{97}$ Speaking on 20 July 1918, Feliks Starzyński (1864-1945) from the PU sketched the issue of evicting Polish peasants from farms formerly belonging to Orthodox farmers who went to bezhenstvo in 1915. According to the Łęczna politician, the abandoned farms would have fallen into ruin and decay had it not been for Polish peasants who "set things right with considerable effort and expenses". 98

Following the 1918 Brest-Litovsk peace with Russia, the Orthodox population started to return to their homes. According to Gazeta Ludowa, this caused Poles to be removed from farms taken over between 1915 and 1918. ${ }^{99}$ In consequence, Starzyński proposed to fill abandoned farms in the Chełm region with Polish settlers. The Council of State ultimately rejected this proposal. ${ }^{100}$ On 25 August 1918, inhabitants of the village of Kobyłka in the Łęczna county petitioned the Council of State that local farms should be handed over to Polish peasants. ${ }^{101}$ The farmers tilled the land belonging to the Orthodox population who departed deep into Russia in 1915. Thirty-three inhabitants of the village of Ludwin near Łęczna used the periodical to argue that Orthodox families returning from Russia are a threat, as eviction in favour of former owners would deprive Polish peasants of their livelihood. ${ }^{102}$ According to Gazeta Ludowa correspondents, the Polish cooperation movement thrived in areas abandoned by the Orthodox. This was the case, among others, in the village of Olchowiec, Chelm county, where the Food Producers Association flourished with the assistance of the local Roman Catholic priest Father Walenty Kowalski (parish priest from 1900 to 1931). ${ }^{103}$ At the same time, the former Chełm and Lublin guberniyas witnessed the birth of Polish education, mainly in the form of village schools. ${ }^{104}$ In parallel, reading in Polish and other Polish cultural activities developed, with periodicals being subscribed to and libraries founded. ${ }^{105}$ Reporting on Starzyński's efforts to defend Chełm and Lublin region farms taken over by the Polish population was the last Orthodoxy-related theme in the discussed periodical.

The Great War reflected on articles published in Gazeta Ludowa from 1915 to 1918. One of the topics addressed was issues related to the Orthodox Church in

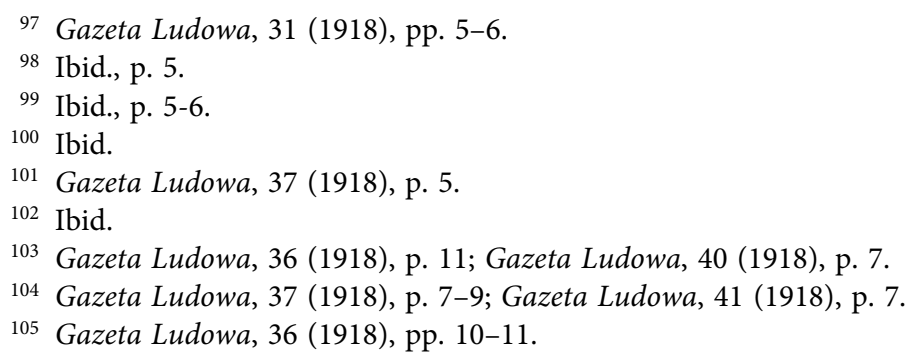


the Chełm region and southern Podlachia, organized as the Chełm eparchy. In the periodical, the authors discussed themes such as war damage, the consequences of evacuating civilians from the Chełm and Lublin guberniyas by the Russian administration and military in 1915, the onset of church buildings recovery by the Roman Catholic Church, and attempts to stage local missions by Jesuits and Greek Catholic clergy. The weekly's journalists highlighted the growing confessional (Catholic-Orthodox), national (Polish-Russian and Polish-Ukrainian) and economic conflicts in the area under consideration. One should emphasise here the clearly drawn opinions of the periodical's writers which were connected to Polish, conservative, nationalist and agrarian interests. These opinions often verged on being radical and showed a lack of understanding of issues of the local, indigenous Orthodox community that was exposed to the disastrous wartime evacuation and its multifarious consequences. The research conclusion presented here is one-sided and reveals the viewpoint of a specific political and editorial group, and needs further, more detailed research. Analysing the periodical serves to indicate an opportunity to elaborate the multi-threaded history of the Chełm eparchy during the Great War.

\section{Chełm Orthodox Diocese as Mentioned in the Gazeta Ludowa. Tygodnik Ilustrowany Weekly from 1915 to 1918}

\section{Abstract}

During the First World War the illustrated weekly Gazeta Ludowa. Tygodnik Ilustrowany was associated with peasant parties: the Polish Peasant Party "Piast" (Polskie Stronnictwo Ludowe "Piast") and the Peasant Union (Zjednoczenie Ludowe). An analysis of the weekly makes it possible to observe the functioning of Chełm Diocese of the Russian Orthodox Church in 1915-1918 in the territories of the Polish Kingdom after its faithful were sent to the Russian hinterland (August 1915). The archival material on the history of the Chełm Orthodox Diocese has been both much destroyed and dispersed, and thus one of the possible ways to study the history of Chełm eparchy is to examine the content of the press published in 1915-1918 in the Polish territories. The illustrated weekly under the analysis touched upon subjects pertaining to war destructions in the diocese of Chełm, consequences of a large number of civilians from the guberniyas of Chełm and Lublin sent to the Russian hinterland by the Russian administration and army in 1915, the first stages of the repossession of the Orthodox Church by the Roman Catholic Church, and attempts to establish local missions by the Jesuit Order and the Greek Orthodox priests. Initial research conclusions could be formulated after a look into the history of the Chełm eparchy before 1914 and at the situation during the first years of the Great War in the whole Chełm region and southern Podlachia. The presented analysis does not exhaust the subject under discussion, but previews it for further study. 


\section{Православная Холмская епархия в 1915-1918 гг. на страницах "Газеты Людовой. Тыгодника илюстрованого»}

\section{Аннотация}

Во время Первой мировой войны «Газета Людова. Тыгодник илюстрованы» (Крестьянская газета. Иллюстрированный еженедельник) была связана с крестьянскими партиями - Польской крестьянской партией «Пяст» и Крестьянским объединением. Анализ журнала делает возможным наблюдение за деятельностью Холмской епархии Российской православной церкви в 1915-1918 гг. на территории Королевства Польского после эвакуации ее верующих вглубь России (август 1915 г.). Архивный материал, касающийся истории вышеупомянутой епархии, был в значительной мере разрушен и разрознен. Одну из возможностей узнать историю Холмской епархии дает исследование содержиеженедельника затрагивались вопросы, касающиеся военных разрушений в епархии, последствий эвакуации гражданского населения Холмской и Люблинской губерний, проведенной российскими администрацией и армией в 1915 г., начала процесса возврата церковных зданий Римско-католической церкви, попыток вести местные миссии орденом иезуитов и греко-католическим духовенством. Предварительные выводы исследования можно будет подвести после ознакомления с деятельностью Холмской епархии до 1914 г., а также с ситуацией, которая сложилась в первые годы Великой войны на Холмщине и в южном Подляшье. Анализ не исчерпывает обсуждаемого вопроса, но является попыткой определить дальнейшее направление исследования.

Перевод Агнешка Поспишил

\section{Bibliography}

\section{Press}

Gazeta Ludowa. Tygodnik Ilustrowany, 1915-1918

\section{Secondary literature}

Akcja burzenia cerkwi prawosławnych na Chełmszczyźnie i Południowym Podlasiu w 1938 roku. Uwarunkowania, przebieg, konsekwencje, ed. G. Kuprianowicz, Chełm, 2009.

Bibliografia historii Polski XIX i XX wieku, vol. 3: 1864-1918, part 1, eds. S. Sokołowska, I. Ossowska, Warszawa, 2000.

Bieńkowski L., "Chełmska diecezja prawosławna”, in: Encyklopedia katolicka, vol. 3, Lublin, 1979.

Cabaj J., "Postawy ludności Chełmszczyzny wobec kwestii przynależności państwowej swych ziem (1912, 1918-1919)”, Kwartalnik Historyczny, 99 (1992).

Cabaj J., Społeczeństwo guberni chelmskiej pod okupacją niemieckq i austriacka w latach I wojny światowej, Siedlce, 2006.

Cimek H., "Ludowcy wobec idei parlamentu polskiego w latach 1918-1919", Polityka i społeczeństwo, 2 (2005).

Cimek H., "Tradycje dezintegracyjne i integracyjne w polskim ruchu ludowym w latach 19141918", Res Historica, 20 (2005). 
Cygan W.K., Wysocki W.J., W służbie Bogu i Ojczyźnie. Służba duszpasterska w polskich formacjach wojskowych 1914-1918, Mińsk Mazowiecki-Warszawa, 2012.

Demjaniuk B., Bieżeńcy, Łomża, 2005.

Dmitruk S., "Obraz Dumy Państwowej w prasie prawosławnej diecezji chełmskiej”, in: $Z$ dziejów pewnego eksperymentu. Parlamentaryzm rosyjski na progu XX stulecia w kontekście kształtowania się świadomości politycznej narodów imperialnej Rosji, eds. A. Duszyk, K. Latawiec, M. Mądzik, Radom, 2008.

Dmitruk S., "Prawosławne Bractwo Przenajświętszej Bogurodzicy w Chełmie (1879-1914)", Lublin, 2012, a doctoral thesis, Maria Curie-Skłodowska University Library in Lublin.

Dmitruk S., "Wspomnienia o powrocie z bieżeństwa w 1923 r. mieszkańca wsi Wilanowo", Białoruskie Zeszyty Historyczne, 43 (2015).

Dmitruk S., “Życie monastyczne na terenie Królestwa Polskiego na przełomie XIX i XX w”, Teka Komisji Historycznej. Oddział PAN w Lublinie, 6 (2009).

Dylągowa H., Dzieje Unii Brzeskiej (1596-1918), Warszawa-Olsztyn, 1996.

Fedoryk J., "Duchowieństwo prawosławne w Królestwie Polskim w latach 1875-1905”, Lublin 2010 (printout of a doctoral thesis stored in the Maria Curie-Skłodowska University Library in Lublin).

Głaz A., "Ewakuacja ludności cywilnej z Lubelszczyzny latem 1915 r"., Annales Universitatis Mariae Curie-Skłodowska, 56 (2001).

Grosfeld L., "Sprawa Chełmszczyzny w 1918 r”., Kwartalnik Historyczny, 1 (1974).

Grzesiak K., Diecezja lubelska wobec prawosławia w latach 1918-1939, Lublin, 2010.

Hornyj M., Makar J., Makar W., Saluk A., Od deportacji do deportacji. Ukraińskie życie społeczno-polityczne na Chełmszczyźnie i Podlasiu (1915-1947). Badania. Wspomnienia. Dokumenty. W trzech tomach, vol. 1: Badania, Czerniowce, 2011.

Hrycak J., Narodziny nowoczesnego narodu, Lublin, 2000.

Katalog czasopism lubelskich, prep. and ed. H. Wolska, Lublin, 1974.

Katalog czasopism lubelskich. G-M, prep. and ed. I. Wójcik, Lublin, 2005.

Klimecki M., Gorlice 1915, Warszawa, 1991.

Korzeniowski M., Mądzik M., Tarasiuk D., Tułaczy los. Uchodźcy polscy w imperium rosyjskim w latach pierwszej wojny światowej, Lublin, 2007.

Korzeniowski M., Na wygnańczym szlaku... Działalność Centralnego Komitetu Obywatelskiego Królestwa Polskiego na Białorusi w latach 1915-1918, Lublin, 2001.

Kuprianowicz G., 1938. Akcja burzenia cerkwi prawosławnych na Chełmszczyźnie i Południowym Podlasiu, Chełm, 2008.

Kuprianowicz G., "Chełm jako ośrodek ukraińskiego ruchu narodowego w XIX i XX w. Zarys problematyki”, in: Na pograniczu kultur, ed. O. Popowicz, Przemyśl, 2000.

Kuprianowicz G., "Ukraińskie życie kulturalno-oświatowe i ekonomiczne na Chełmszczyźnie i Południowym Podlasiu w latach 1918-1926”, Rocznik Chetmski, 1 (1995).

Latawiec K., "Ewakuacja cywilnej administracji ogólnej szczebla powiatowego z guberni lubelskiej latem 1915 r"., Wschodni Rocznik Humanistyczny, 1 (2004).

Latawiec K., W służbie imperium... Struktura społeczno-zawodowa ludności rosyjskiej na terenie guberni lubelskiej $w$ latach 1864-1915, Lublin, 2007.

Latawiec K., "Ewakuacja organów władzy administracji ogólnej wyższego i niższego szczebla guberni lubelskiej w 1914 r"., Radzyński Rocznik Humanistyczny, 2 (2002).

Leśniewska D., "Problem unicki na łamach 'Polaka”, in: Martyrologia Unitów Podlaskich w świetle najnowszych badań naukowych. Unici Podlascy, vol. 1, eds. J. Skowronek, U. Maksymiuk, Siedlce, 1996.

Lewandowski J., Królestwo Polskie wobec Austro-Wegier. 1914-1918, Warszawa-Łódź, 1986.

Lewandowski J., Na pograniczu. Polityka władz państwowych wobec unitów Podlasia i Chełmszczyzny. 1772-1875, Lublin, 1996. 
Lewandowski J., “Sprawa chełmska w czasie pierwszej wojny światowej”, in: Mychajło Hruszewski i jego Mała Ojczyzna - Chełmszczyzna w XIX-XX wieku, ed. G. Kuprianowicz, Chełm, 2011.

Łojek J., Myśliński J., Władyka W., Dzieje prasy polskiej, Warszawa, 1988.

Mazurek J., Kraj a emigracja. Ruch ludowy wobec wychodźstwa chłopskiego do krajów Ameryki Łacińskiej (do 1939 roku), Warszawa, 2006.

Pajewski J., Pierwsza Wojna Światowa 1914-1918, Warszawa 1991.

Pękała K.P., abstract of the doctoral dissertation "Migracje ludności guberni chełmskiej w pierwszych latach wielkiej wojny (1914-1916)", Lublin, 2012 (private collection of the author).

Pękała K., “Tomaszów Lubelski w pierwszym roku 'Wielkiej Wojny”, in: Roztocze. Historia i kultura, vol. 1, Tomaszów Lubelski-Lubaczów, 2011.

Prasa polska w latach 1864-1918, eds. Z. Kmiecik et al., Warszawa, 1976.

Reymont W., Z Ziemi Chetmskiej. Wrażenia i notatki, Warszawa, 1990.

Roszczenko M., "Kwestia tożsamości ruskiej (ukraińskiej) ludności Chełmszczyzny i Południowego Podlasia w XIX wieku”, in: Mychajło Hruszewski i jego Mała Ojczyzna - Chełmszczyzna w XIX-XX wieku, ed. G. Kuprianowicz, Chełm, 2011.

Serczyk W.A., Historia Ukrainy, Wrocław, 2001.

Sula D., Powrót ludności polskiej z byłego Imperium Rosyjskiego w latach 1918-1937, Warszawa, 2013.

Sulimierski W.Z., Oświata i życie kulturalno-społeczne Chełma w latach 1864-1939, Chełm, 2008.

Sygowski P., "Stan ilościowy cerkwi na terenie Lubelszczyzny (prawosławna diecezja chełmska) w 1914 roku. Próba ustalenia stanu faktycznego", Wschodni Rocznik Humanistyczny, 1 (2004).

Szabaciuk A., 'Rosyjski Ulster'. Kwestia chetmska w polityce imperialnej Rosji w latach 1863-1915, Lublin, 2013.

Trojnacka M., "Pietrzykowski Jozafat (Józafat) (1863-1932)”, in: Słownik biograficzny miasta Lublina, vol. 3, eds. T. Radzik, A.A. Wituski, J. Ziółek, Lublin, 2009.

Wasilewski L., "Ukraińcy rosyjscy wobec Chełmszczyzny i Podlasia”, Kultura Polski, 8 (1918).

Willaume M., "Działania zbrojne Rumunii podczas I wojny światowej w świetle doniesień lubelskiej Gazety Ludowej (1916-1917)”, in: W stużbie Klio... Księga poświęcona pamięci Profesora Tadeusza Radzika, eds. J. Kłapeć, W. Kozyra, G. Kuprianowicz, R. Litwiński, M. Mazur, M. Sioma, R. Wysocki, Lublin, 2012.

Wrzyszcz A., Gubernia chetmska. Zarys ustrojowy, Lublin, 1997.

Zgórniak M., 1914-1918. Studia i szkice $z$ dziejów Wojny Światowej, Kraków, 1987.

Бежанства 1915 года, еd. В. Луба, Беласток, 2000.

Железнякович С., История Яблочинского Свято-Онуфревского монастыря, vol. 2, Варшава, 2007.

Купріянович Г., “Холмське видання з Москви. „Холмський Украінський Календар на 1918 рік” як джерело для вивчення формування української нацйональної ідентичності холмщаків", in: Mychajło Hruszewski i jego Mała Ojczyzna - Chełmszczyzna w XIX-XX wieku, ed. G. Kuprianowicz, Chełm, 2011.

Третяк Л., “Холмська духовна семінарія в 1875-1915 роках”, in: Украйниі Холмщзини і Підляшшя: Історічн доля, духовна і матеріавна култура впродовж віків. Збірник наукових прац, , vol. 2, Луцьк, 2010.

Федорик Ю., Православне духовенство в Царстві Полському в 1875-1905 роках, Донецьк, 2013. 
Stefan Dmitruk (b. 1980) received his doctoral degree from Maria Curie-Skłodowska University in Lublin in 2012. Author of 47 scientific articles, he published in periodicals: Białoruskie Zeszyty Historyczne, Res Historica, Teki Komisji Historycznej Oddziału Lubelskiego PAN, and collections of studies in Poland, Ukraine and Russia. His scientific interests include: the Orthodox Church, ethnic and religious problems, and Russian community in the Kingdom of Poland in the second half of the nineteenth century and evacuations of civilians deep into Russia in First World War (dmitruk.stefan@gmail.com). 